\title{
Risoterapia, Besterologia e Clown Visitador: Compreendendo Abordagens Clownescas Humanizadoras da Saúde
}

\author{
Medeiros, Jessica Farias Dantas \\ Instituto Federal de Educação Ciência e Tecnologia do Ceará — fariasjessicad@yahoo.com.br
}

INTRODUÇÃO Devido ao seu caráter humanizador, terapêutico e profilático, o clown e sua essência cômica ganharam destaque e reconhecimento na rotina hospitalar de diversos países. Três de suas abordagens contribuem para a ascensão da linguagem clownesca nesse espaço: a Risoterapia, Besterologia e Clown Visitador. Elas, muitas vezes, são confundidas entre si, mesmo sendo distintas em suas aplicações técnicas. Mas quais são suas verdadeiras divergências, já que todas fazem parte da busca dessa humanização na saúde? que relevância essa interface entre seus conceitos pode gerar para os grupos que as pesquisam? a fim de responder essas perguntas, este artigo surgiu, almejando também dialogar sobre seus objetivos. OBJETIVOS Analisar três abordagens clownescas em hospitais, apontando suas divergências para aprofundar a discussão do tema e esclarecer possíveis equívocos que venham a surgir, a fim de contribuir para um maior entendimento dessa arte e sua multiplicidade de aplicação, no processo de humanização hospitalar. MÉTODOS Adotamos como metodologia o estudo bibliográfico, com um extenso referencial teórico, do qual destacamos: a Terapia do Amor (2002), de Patch Adams; Boas Misturas - a ética da alegria no contexto hospitalar (2003), de Morgana Masetti; e o clown visitador: comicidade, arte e lazer para crianças hospitalizadas (2011), de Ana Elvira Wuo. Obras de fundamental importância para os levantamentos discorridos e reorganizados durante o desenvolvimento e análise dos conteúdos. RESULTADOS Risoterapia, Besterologia e Clown Visitador se destacam como linhas de pesquisa e trabalhos voluntários que encontraram na linguagem circense a base artística para alcançar os seus anseios. a primeira, fomentada pelo médico norte-americano Patch Adams, acredita no caráter terapêutico do riso, visando à aproximação, através do palhaço, entre médico e paciente, criandose um ambiente de assistência hospitalar baseado no bom humor. Já o caráter não terapêutico tanto da Besterologia, desenvolvida por Wellington Nogueira, como do Clown Visitador, de Ana Elvira Wuo, acabam por instaurar nos hospitais brasileiros a técnica de atores clowns em prol do bem estar, de momentos prazerosos e da alegria numa rotina tão estressante para pacientes, família e equipe médica. CONCLUSÕES Percebe-se que as três principais abordagens de palhaçaria por nós estudadas utilizam a mesma figura, a do clown, no trato com as pessoas circundantes do espaço hospitalar, mas entendem a sua função de modo distinto, enquanto a Risoterapia reconhece a possibilidade de cura a partir do riso, a Besterologia e o Clown Visitador investem na força do encontro e no riso como resgate da vitalidade presente, definindo os fins terapêuticos como consequência. Acreditamos que nossa pesquisa ajudará estudos posteriores sobre clown no ambiente hospitalar, no sentido de oferecer uma visão mais homogênea sobre as abordagens e evitando que se construam imagens inequívocas da figura e função do palhaço.

Medeiros, Jessica Farias Dantas. Risoterapia, Besterologia e Clown Visitador: Compreendendo Abordagens Clownescas Humanizadoras da Saúde.. In: Anais do Congresso Internacional de Humanidades \& Humanização em Saúde [= Blucher Medical Proceedings, num.2, vol.1]. São Paulo: Editora Blucher, 2014. ISSN 2357-7282 DOI 10.5151/medpro-cihhs-10841 